\title{
CLASSIFICATION OF DIABETIC FEET IN TERMS OF RISK OF ULCERATION
}

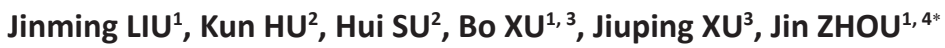 \\ ${ }^{1}$ National Engineering Laboratory for Clean Technology of Leather Manufacture, Sichuan University; Chengdu 610065, \\ P.R.China \\ ${ }^{2}$ Guangdong Huizhou Quality \& Measuring Supervision Testing Institute; Huizhou 516003, China \\ ${ }^{3}$ School of Business, Sichuan University; Chengdu 610065, P.R. China \\ ${ }^{4}$ Chengdu Anland Co., LTD; Chengdu 610065, P.R. China
}

Received: 13.03.2017

Accepted: 10.05 .2017

https://doi.org/10.24264/Ifj.17.3.2

\section{CLASSIFICATION OF DIABETIC FEET IN TERMS OF RISK OF ULCERATION}

\begin{abstract}
Diabetic feet are common complications in diabetes mellitus, but its classification in terms of risk of ulcer based on multiple measures was rear reported. Therefore the aim of this study was to establish a classification system for diabetic feet according to data from feet deformities, plantar pressures and peripheral neuropathy. This system comprised 13 categories with three main factors in varied levels: Feet deformities [Mild (one or without deformity), Moderate (two deformities) and Severe level (more than two deformities)], peripheral neuropathy (no, moderate and serious levels) and plantar pressure distribution ( $\leq 100 \% \mathrm{MP} * ; 100 \leq$ and $\leq 120 \% \mathrm{MP} *$; more than $120 \% \mathrm{MP}$, where "MP*" is the data of healthy population). Further, we conducted a case study to explain of our system, the results show that 32 patients with diabetes were divided into the following categories: 22 for I++, 8 for II+, 2 for IV+. Overall, This system can help the clinician detect the risk levels of feet and take necessary measures to prevent diabetic ulcers in feet.
\end{abstract}

KEY WORDS: diabetic feet, feet ulcers, classification of diabetic feet, feet deformity, plantar pressure distribution

\section{CLASIFICAREA PICIORULUI DIABETIC ÎN FUNCȚIE DE RISCUL DE ULCERATIIE}

REZUMAT. Piciorul diabetic reprezintă o complicație frecventă a diabetului zaharat, însă rareori s-a raportat clasificarea acestuia în ceea ce privește riscul de ulcerație pe baza mai multor măsurători. Prin urmare, scopul acestui studiu a fost de a stabili un sistem de clasificare pentru piciorul diabetic, în funcție de datele privind deformarea picioarelor, presiunea plantară și neuropatia periferică. Acest sistem a cuprins 13 categorii cu trei factori principali pe diverse niveluri: deformări ale picioarelor [ușoare (o singură deformare sau fără deformare), moderate (două deformări) și severe (mai mult de două deformări)], neuropatie periferică (lipsa acesteia, nivel moderat și nivel mare) și distribuția presiunii plantare ( $\leq 100 \% \mathrm{MP} * ; 100 \leq$ și $\leq 120 \% \mathrm{MP} *$; peste $120 \% \mathrm{MP} *$, unde "MP*” reprezintă datele populației sănătoase). Mai mult, s-a realizat un studiu de caz pentru a explica sistemul dezvoltat, iar rezultatele arată că 32 de pacienți cu diabet au fost împărțiți în următoarele categorii: 22 în categoria I++; 8 în categoria II+; 2 în categoria IV+. În ansamblu, acest sistem poate ajuta clinicianul să detecteze nivelurile de risc ale picioarelor și să ia măsurile necesare pentru prevenirea ulcerațiilor asociate cu piciorul diabetic.

CUVINTE CHEIE: picior diabetic, ulcerații la nivelul picioarelor, clasificarea piciorului diabetic, deformarea picioarelor, distribuția presiunii plantare

\section{CLASSIFICATION DES PIEDS DIABÉTIQUES SELON LE RISQUE D’ULCÉRATION}

RÉSUMÉ. Le pied diabétique est une complication fréquente dans le diabète sucré, mais sa classification selon le risque d’ulcération à partir des mesures multiples a été signalée rarement. Par conséquent, l'objectif de cette étude a été d'établir un système de classification pour le pied diabétique selon les données sur les déformations des pieds, les pressions plantaires et la neuropathie périphérique. Ce système a compris 13 catégories avec trois facteurs principaux sur des niveaux variés: les déformations des pieds [légères (une ou sans déformation), modérées (deux déformations) et sévères (plus de deux déformations)], la neuropathie périphérique (absence, niveaux modéré et sérieux) et la distribution de la pression plantaire ( $\leq 100 \% \mathrm{MP} * ; 100 \leq$ et $\leq 120 \% \mathrm{MP}$; ; plus de $120 \%$ MP*, où "MP*" signifie les données d'une population saine). En outre, on a réalisé une étude de cas pour expliquer notre système et les résultats montrent que 32 patients atteints de diabète ont été divisés dans les catégories suivantes: 22 pour I++; 8 pour II+; 2 pour IV+. Dans l'ensemble, ce système peut aider le clinicien à détecter les niveaux de risque des pieds et à prendre les mesures nécessaires pour prévenir les ulcères du pied diabétique.

MOTS CLÉS: pied diabétique, ulcères de pieds, classification du pied diabétique, déformation des pieds, distribution de la pression plantaire

\section{INTRODUCTION}

Diabetic feet refers to the lower limb of diabetic patients and it usually concerns the different degrees of peripheral vascular/ neuropathy disease, feet deformity, feet infection, ulcers or deep tissue damage [1]. Ulceration is also one of the most common and serious complications causing lower limb amputations for diabetes mellitus. As estimated, annual incidence of lower limb amputation was about $0.015 \%$ in current report, where half of them was attributed to the diabetic feet [2]. Besides, a heavy financial burden produced in diabetic population was 3 to 4 times higher than

*Correspondence to: Dr. Jin Zhou, National Engineering Laboratory for Clean Technology of Leather Manufacture, Sichuan University; Chengdu 610065, P.R.China; zj_scu@qq.com 
that of non-diabetics [3]. Therefore, it is essential to build a classification system to identify the risk of diabetic feet in terms of ulceration and then to make efforts to prevent the occurrence of ulcers.

Currently, the main methods for feet ulcer prevention are: (1) stressing the important of education in feet protection, as studies have shown that without enough education, the occurrence rates of amputation was 2 folds higher than the counterparts [4]; (2) screening the feet frequently [5]; (3) taking care of feet and choosing the right footwear [4]; (4) control diet and blood glucose. Among them, feet inspection, such as analysis of medical history, peripheral neuropathy measure $[6,7]$, plantar pressure test [8], feet deformity confirmation [9] and tissue thickness measure under skin by ultrasonic examination [10] or nuclear magnetic resonance [11] were important. However, current literature described the feet conditions by some aspects of the examination, for instance, diabetic peripheral neuropathy (DPN) merely combined the results of feet morphology inspection and feet peripheral neuropathy screen, other important information such as plantar pressure distribution was ignored. Hence, general outcomes in assessing the potential ulcer risk of diabetic feet could not be concluded.

Therefore, the aim of this study was to improve the traditional DPN approach and to establish an ulcer risk classification system for diabetic patients based on the assessment of feet deformity, plantar pressure and peripheral neuropathy. At last the diabetic feet can be explicitly classified into various groups and received differentiated treatment.

\section{METHODS}

\section{Method of Diabetic Feet Examination}

\section{Feet Deformities Inspection [9]}

Hallux valgus, hammer toe and claw toe belong to the categories of deformed feet. Hallux valgus occurs in the hallux and the MTH1, which can be expressed by the degree of the hallux valgus angle $(\mathrm{AOH})$. Hallux valgus angle $(\mathrm{AOH})$ can be measured by the relative position with hallux and MTH1 (Figure 1A). While, hammertoe refers to the deformity in hallux, which is in a vertical status and can greatly rise its pressure volume (Figure 1B); similarly, claw toe is similar to the hammer-toe, but the deformity occurs in the toe areas (Figure 1C). Those three deformities were usually observed in the diabetic patients [9]. However, as deformities such as pes planus or pes cavus were also common in the healthy population and whether they shall be considered as deformity or not has not been under the conclusion.

Numbers or types deformities were used to determine the feet deformities: Mild (one deformity or without deformity), Moderate (two deformities) and Severe level (multiple deformities).



Figure 1. Samples of hallux valgus (A), hammer-toe (B) and claw toe (C)

Plantar Pressure Assessment [12]

Distribution of plantar forces was obtained by the Footscan plantar pressure system (one meter plate, RSscan Int., Belgium). The scanning frequency of this system is $250 \mathrm{~Hz}$, the pressure sensor density is $4 / \mathrm{cm}^{2}$ and the range of measurement is $0-200 \mathrm{~N} / \mathrm{cm}^{2}$. A two-step initial 
protocol [8] was performed by the subjects and they were guided to walk with their selected speed through the pressure plate, which was located and embedded in the middle of a sixmeter track. Before each measurement, the system was calibrated; and then a three to five minute warm up period was provided. At least three successful measures of each side of the foot were required in this study and they were averaged for further classification.

The plantar regions were divided by the Footscan software into 7 parts (Figure 1): the hallux, the first to fifth metatarsal heads $\left(1^{\text {st }}\right.$ to $\left.5^{\text {th }} \mathrm{MTH}\right)$ and the midfoot (MF), under which mean pressure (MP) $\left(\mathrm{N} / \mathrm{cm}^{2}\right)$ was calculated. The rearfoot areas such as medial heel and lateral heel were ignored, since seldom has ulcer occurred in those areas.

A group of healthy participants [94 healthy people (47 normal male / 47 normal female)] was measured to build a criterion. Their mean age of their counterparts is $64.0 \pm 7.4$ years, mean height is $157.0 \pm 7.4 \mathrm{~cm}$, body weight is $59.5 \pm 9.6$ $\mathrm{Kg}$ and mean $\mathrm{BMI}$ is $24.0 \pm 3.0$. Moreover, their MP at hallux is $13.1 \pm 8.6 \mathrm{~N} / \mathrm{cm}^{2}, \mathrm{MTH} 1$ is $9.1 \pm 7.4 \mathrm{~N} /$ $\mathrm{cm}^{2}, \mathrm{MTH} 213.6 \pm 7.6 \mathrm{~N} / \mathrm{cm}^{2}, \mathrm{MTH} 313.2 \pm 6.2 \mathrm{~N} /$

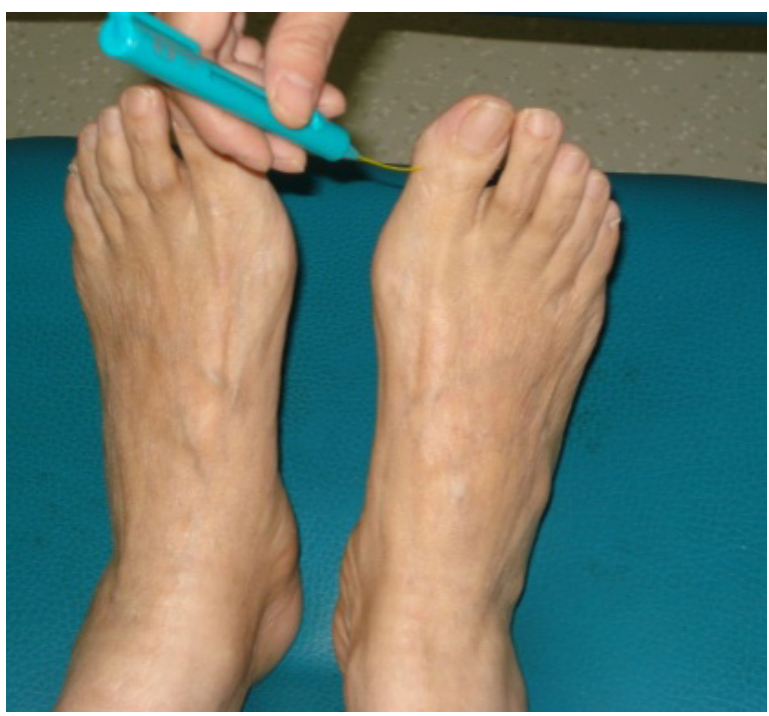

$\mathrm{cm}^{2}, \mathrm{MTH} 49.0 \pm 3.5 \mathrm{~N} / \mathrm{cm}^{2}, \mathrm{MTH} 5$ is $10.2 \pm 7.1 \mathrm{~N} /$ $\mathrm{cm}^{2}$, and $\mathrm{MF}$ is $4.4 \pm 2.2 \mathrm{~N} / \mathrm{cm}^{2}$.

\section{DPN (Diabetic Peripheral Neuropathy)}

DPN included the Michigan self-test and feet inspection. A standard Michigan self-test table was provided for the patients and feet inspection was made by an experienced staff which includes algesia and vibration check. The procedure of algesia test was made by $10 \mathrm{~g}$ Nylon monofilament [6]. Patient's bipedal toes were pressed by the monofilaments; then scores were calculated: 0 for normal feel, 1 for disappeared feel and 0.5 for the weakened feel (Figure 3 ). The tuning fork with vibration frequency of $128 \mathrm{~Hz}$ was placed in the bony protrusion of hallux [7] and score was given as 0 for normal with the feeling time <10s, 1 for disappear feel, and 0.5 for weakened with the feeling time $>10$ s (Figure 2). Moreover, the DPN was scored by the same scorer.

The classification of DPN was shown as: DPN score $=0$ indicates no peripheral neuropathy; $0<$ DPN score $<3$ implied moderate; $3<$ DPN score showed severe.



Figure 2. Demonstration of DPN test (A: algesia test; B: vibration test)

\section{Diabetic Feet Classification System}

In our systems, diabetic feet can be overall evaluated through three main factors in varied levels: Feet deformity [Mild (one deformity or without deformity), Moderate (two deformities) and Severe level (multiple deformities)],
Peripheral neuropathy (no, moderate and serious levels) and Plantar pressure distribution ( $\leq 100 \% \mathrm{MP}^{*} ; 100 \leq$ and $\leq 120 \% \mathrm{MP} *$; more than $120 \% \mathrm{MP}^{*}$, where "MP*" is the data of healthy population). So 13 categories were developed (Table 1). 
Table 1: System for diabetic feet classification

\begin{tabular}{|c|c|c|}
\hline & Category & Description \\
\hline 1 & $\begin{array}{l}\text { (mild / normal deformity) \& (normal DPN) \& (pressure } \\
\leq 100 \% \mathrm{MP}^{*} \text { ) }\end{array}$ & under healthy condition \\
\hline I+ & $\begin{array}{l}\text { (mild / normal deformity) \& (normal DPN) \& }(100 \% \\
\left.\text { MP* } \leq \text { pressure } \leq 120 \% \mathrm{MP}^{*}\right)\end{array}$ & $\begin{array}{l}\text { without feet deformity and peripheral neuropathy, but } \\
\text { with slightly high plantar pressure }\end{array}$ \\
\hline I++ & $\begin{array}{l}\text { (mild / normal deformity) \& (normal DPN) \& (pressure } \\
\geq 120 \% \mathrm{MP}^{*} \text { ) }\end{array}$ & $\begin{array}{l}\text { without feet deformity and peripheral neuropathy, but } \\
\text { with significantly high plantar pressure }\end{array}$ \\
\hline II & $\begin{array}{l}\text { (mild / normal deformity) \& (moderate DPN) \& } \\
\text { (pressure } \leq 100 \% \mathrm{MP}^{*} \text { ) }\end{array}$ & $\begin{array}{l}\text { without feet deformity, but with moderate peripheral } \\
\text { neuropathy }\end{array}$ \\
\hline II+ & $\begin{array}{l}\text { (mild / normal deformity) \& (moderate DPN) \& } \\
\text { (pressure } \geq 120 \% \mathrm{MP}^{*} \text { ) }\end{array}$ & $\begin{array}{l}\text { without feet deformity, but with moderate peripheral } \\
\text { neuropathy and significantly high plantar pressure }\end{array}$ \\
\hline $\mathrm{III} * *$ & $\begin{array}{l}\text { (mild / normal deformity) + (severe DPN) \& (pressure } \\
\leq 100 \% \mathrm{MP}^{*} \text { ) }\end{array}$ & \\
\hline $\mathrm{IV} * *$ & $\begin{array}{l}\text { (moderate deformity) \& (normal DPN })+\left(100 \% \mathrm{MP}^{*} \leq\right. \\
\left.\text { pressure } \leq 120 \% \mathrm{MP}^{*}\right)\end{array}$ & \\
\hline IV+ & $\begin{array}{l}\text { (moderate deformity) \& (normal DPN) \& (pressure } \geq \\
120 \% \mathrm{MP}^{*} \text { ) }\end{array}$ & $\begin{array}{l}\text { with two deformities and significantly high plantar } \\
\text { pressure, without peripheral neuropathy }\end{array}$ \\
\hline V & $\begin{array}{l}\text { (moderate deformity) \& (moderate DPN) \& }(100 \% \\
\left.\mathrm{MP}^{*} \leq \text { pressure } \leq 120 \% \mathrm{MP} *\right)\end{array}$ & $\begin{array}{l}\text { with two deformities, moderate peripheral neuropathy } \\
\text { and slightly high plantar pressure }\end{array}$ \\
\hline VI & $\begin{array}{l}\text { (moderate deformity) \& (severe DPN) \& }\left(100 \% \mathrm{MP}^{*} \leq\right. \\
\left.\text { pressure } \leq 120 \% \mathrm{MP}^{*}\right)\end{array}$ & $\begin{array}{l}\text { with two deformities, severe peripheral neuropathy and } \\
\text { slightly high plantar pressure }\end{array}$ \\
\hline $\mathrm{VII} * *$ & $\begin{array}{l}\text { (severe deformity) \& (normal DPN) \& (pressure } \geq 120 \% \\
\text { MP*) }\end{array}$ & \\
\hline VIII & $\begin{array}{l}\text { (severe deformity) \& (moderate DPN) \& (pressure } \geq \\
120 \% \mathrm{MP}^{*} \text { ) }\end{array}$ & $\begin{array}{l}\text { with multiple deformities, moderate peripheral } \\
\text { neuropathy and significantly high plantar pressure }\end{array}$ \\
\hline IX & $\begin{array}{l}\text { (severe deformity) \& (severe DPN) \& (pressure } \geq 120 \% \\
\mathrm{MP}^{*} \text { ) }\end{array}$ & $\begin{array}{l}\text { with multiple deformities, severe peripheral neuropathy } \\
\text { and significantly high plantar pressure }\end{array}$ \\
\hline
\end{tabular}

*: MP of the healthy population

**: This situation is relatively rare (deformity and DPN are usually associated with high MP, or vice versa)

\section{CASE STUDIES}

In order to explain our system, we conducted a case study as shown below:

In this case study, diabetic patients were from Chengdu, including 19 males and 13 females; their height ranges from $151 \mathrm{~cm}$ to $182 \mathrm{~cm}$ and mean is $162.8 \pm 8.5 \mathrm{~cm}$; weight ranges from 40 to $120 \mathrm{~kg}$ and mean is $64.9 \pm 15.8 \mathrm{~kg}$; BMI ranges from 16.0 to 36.6 and mean is $24.3 \pm 4.4$. All the measures were executed after the details of this study were introduced to participants and their formal approvals were obtained. Moreover, all the measurements and procedures followed the principles of Helsinki Declaration.

In terms of feet deformities, there were 2 cases with moderate feet deformity, accounting for 6.25\%; while Michigan self-test score ranged
$0-5$ points and mean was $0.83 \pm 1.21$ points. Further, the number of regions belong to category of " $100 \%$ <plantar pressure <120\%" were: 1 for Hallux (left), 2 for MTH1 (left), 6 for MTH2 (left), 4 for MTH3 (left), 2 for MTH4 (left), 5 for MTH5 (left), 5 for MF (left); 1 for Hallux (right), 2 for MTH1 (right), 2 for MTH2 (right), 2 for MTH3 (right), 3 for MTH4 (right), 7 for MF (right). Those for the category of " $120 \%<$ plantar pressure" were: 9 for MTH1 (left), 16 for MTH2 (left), 25 for MTH3 (left), 26 for MTH4 (left), 12 for MTH5 (left), 8 for MF (left); 2 for Hallux (right), 9 for MTH1 (right), 17 for MTH2 (right), 23 for MTH3 (right), 24 for MTH4 (right), 10 for MTH5 (right), 7 for MF (right).

Thereby, according to the classification system, 32 patients with diabetes were divided 
into the following categories: 22 for I++; 8 for II+; 2 for IV+.

\section{DISCUSSION}

The structural change in the forefoot caused by hallux valgus resulted in the degradation of weight bearing function under hallux and first metatarsal head and the simultaneous worsening of the loading bearding at the lateral forefoot [13, 14]. Correlations between foot deformities and the changes of foot loading of the diabetic patient were widely reported in current literature. Mueller et al. [15] found that an increasing hallux valgus rendered the great toe less effective in weight bearing and a negative correlation was observed between high peak pressure and the great toe; while positive correlation existed between high peak pressure and first MTH. This was consistent with the study of Ahroni et al. [16] who systematically reviewed the risk factors for diabetic feet ulcer and they concluded that feet deformities significantly increased plantar pressure. However, conflicting results of hallux valgus were obtained by Ledoux et al. [14], but they also showed that claw toes and hammer toes were strongly correlated with the high pressure and the occurrence of feet ulcers. Based on the above studies, we chose the hallux valgus, hammer toes and claw toes as indicators for evaluating the degree of foot deformities by counting the number and type of deformities.

In terms of pressure distribution, Bus et al. [17] demonstrated that peak pressure of diabetic feet was more than $600 \mathrm{kPa}$ in a specific MTH area; meanwhile Bus et al. [18] also recommended that mean pressure $100 \mathrm{kPa}$ or peak pressure $200 \mathrm{kPa}$ shall be selected as target for pressure relieving. So in our study, we set two numbers as criterion: one is the $100 \%$ of healthy counterpart; another is the $120 \%$ of diabetic patients. In accordance with the healthy subjects, main loading area such as MTH1 has MP of $9.1 \pm 7.4 \mathrm{~N} / \mathrm{cm}^{2}$, the $120 \%$ of this value is $10.9 \mathrm{~N} / \mathrm{cm}^{2}(109 \mathrm{kPa})$ which reached the level recommended in the literature. Hence, we deemed that $120 \%$ MP of healthy population was enough to detect the risk of pressure distribution.

In our practice, with the assistance of this system based on evaluation of foot deformity, plantar pressure and peripheral neuropathy, the clinician can easily classify the patients into varied groups and further prescription can be made accordingly. However, limitations existed in our study: (1) only the three types of deformity were considered in this study, where those of the amputated feet or feet with ulceration were not recruited in this study; (2) the peak pressure under the rear feet such as medial and lateral heel were not considered in this study; (3) validities of this system shall be improved by application of more cases. Nevertheless, this part of work will be continuously carried out in the future.

\section{CONCLUSION}

Overall, In this study, we developed a classification system based on assessment of feet deformity, plantar pressure and peripheral neuropathy. This system can help the clinician detect the risk levels of feet and take necessary measures to prevent diabetic ulcers in feet.

\section{Acknowledgement}

The authors thank the financial support from China Postdoctoral Science Foundation (2015M571896) and project from Chengdu science and technology administration (2015-HM01-00039-SF).

\section{REFERENCES}

1. International Diabetes Feet Working Group, International Consensus on the Diabetic Feet, 2003.

2. Apelqvist, J., Larsson, J., Diabetes Metab Res Rev, 2000, 16, 75-83.

3. Li, Q., Wang, P.H., Yan, L., Du, Y.M., Bian, R.W., Wang, Z.J., Mao, J.P., Xiao, Z.H., Ma, X.Y., Lin, S.D., Chen, G.C., Zhou, Y.S., Xu, Z.R., Chinese Journal of Endocrinology and Metabolism, 2005, 21, 496-499.

4. Coleman, W.C., Brand, P.W., Ellenberg and Rifkin's Diabetes Mellitus, 1997, 1159-1182.

5. The American Diabetes Association, Diabetes Care, 1998, 21, 554-555.

6. McGill, M., Molyneaux, L., Spencer, R., Heng, L.F., Yue, D.K., Diabetes Care, 1999, 22, 598602. 
7. Xu, Z.R., Chinese Journal of Endocrinology and Metabolism, 2005, 6, 491-493.

8. Barnett, S., Diabetic Feet, 1998, 1, 72.

9. Zhou, J., Xu, B., Principle of the Last Design, 2016, 65-69.

10. Boulton, A.J.M., Diabetologia, 2004, 49, 1342-1353.

11. Li, Q.X., Medicine and Philosophy, 2008, 29, 14-17.

12. Wang, A.H., Li, J.L., Xu, Z.R., Wang, Y.Z., Liu, Y., Chin J Endocrinol Metab, 2005, 21, 500-501.

13. Hutton, W.C., Dhanendran, M., Clin Orthop Relat Res, 1981, 157, 7-13.

14. Ledoux, W.R., Shofer, J.B., Smith, D.G., Sullivan, K., Hayes, S.G., Assal, M., Reiber, G.E., J Rehabil Res Dev, 2005, 42, 5, 665-672.
15. Mueller, M.J., Hastings, M., Commean, P.K., Smith, K.E., Pilgram, T.K., Robertson, D., Johnson, J., J Biomech, 2003, 36, 1009-1017.

16. Ahroni, J.H., Boyko, E.J., Forsberg, R.C., Diabetes Care, 1999, 22, 965-972.

17. Bus, S.A., Maas, M., de Lange, A., Michels, R.P., Levi, M., J Biomech, 2005, 38, 19181925.

18. Bus, S.A., Haspels, R., Buschwestbroek, T.E., Diabetes Care, 2011, 34, 7, 1595.

C 2017 by the author(s). Published by INCDTPICPI, Bucharest, RO. This is an open access article distributed under the terms and conditions of the Creative Commons Attribution license (http://creativecommons.org/licenses/by/4.0/). 